Research Article

Published April 9, 2017

\title{
Hurdles to the Development of EFFECTIVE HBV IMMUNOTHERAPIES AND HCV VACCINES
}

\section{AUTHORS}

Almudena Torres-Cornejo ${ }^{1}$, Georg M. Lauer $^{1}$

\section{AFFILIATED INSTITUTION}

${ }^{1}$ Gastrointestinal Unit and Liver Center, Massachusetts General Hospital and Harvard Medical School, Boston, Massachusetts

\section{CORRESPONDING AUTHOR}

Georg M. Lauer

Gastrointestinal Unit

Massachusetts General Hospital and Harvard Medical School

55 Fruit Street

Boston, MA 02114

617-724-7515

glauer@mgh.harvard.edu

\section{D0I}

10.20411/pai.v2i1.201

\section{SUGGESTED CITATION}

Torres-Cornejo A, Lauer GM. Hurdles to the Development of Effective HBV Immunotherapies and HCV Vaccines. Pathogens and Immunity. 2017;2(1):102-125. doi: 10.20411/pai.v2i1.201

\section{ABSTRACT}

Chronic infections with HBV and HCV continue to be major public health problems, with hundreds of millions of people infected worldwide; this is despite the availability of both an effective prophylactic $\mathrm{HBV}$ vaccine for more than 3 decades and potent direct antivirals for HBV and, more recently, HCV infection. Consequently, development of HBV immunotherapies and prophylactic $\mathrm{HCV}$ vaccines remains extremely urgent, but limited funding and significant gaps in our understanding of the correlates of immune protection pose serious hurdles for the development 
of novel immune-based interventions. Here we discuss immunological questions related to HBV and $\mathrm{HCV}$, some shared and some pertinent to only 1 of the viruses, that should be addressed for the rational design of $\mathrm{HBV}$ immunotherapies and $\mathrm{HCV}$ vaccines.

Keywords: hepatitis- $B$, hepatitis- $C$, research funding, immune response, $T$ cell, antibodies, vaccine, immunotherapy

\section{CHRONIC VIRAL HEPATITIS: A CONTINUED CHALLENGE TO GLOBAL HEALTH}

Chronic viral hepatitis remains a vast global health problem. Around 360 million people worldwide are chronically infected with hepatitis B virus (HBV) and 130-150 million with hepatitis C (HCV) [1-3]. Together, these two infections are the cause of death for approximately 1.4 million people every year. Despite the availability of effective HBV vaccines and antiviral treatments, and the recent introduction of powerful direct-acting antivirals (DAAs) for HCV, we are not close to reasonably claiming "Mission Accomplished", if our goals are to eliminate or even significantly diminish disease from these 2 hepatotropic infections in all parts of the world.

Three decades have passed since the first recombinant HBV vaccine was approved in the United States [4], and HBV vaccines have been shown to be safe and effective in $>90$ percent of those vaccinated against all HBV serotypes and genotypes. The implementation of comprehensive HBV vaccination programs has now resulted in a significant decrease in the incidence and prevalence of HBV infection, but only in countries where the local resources enabled the establishment of these programs some decades ago []‥ In recent years we have seen further increases in the worldwide use of the HBV vaccine, with the WHO estimating in 2015 that $83 \%$ of all 1 -year-olds had received a third dose of $\mathrm{HBV}$ vaccine. Nevertheless, substantial vaccination gaps exist, especially in many parts of Africa [ $[6,7]$. Given the long delay between the establishment of effective vaccination programs and their impact on the prevalence of chronic HBV infection [8] , the challenge of effectively treating millions of chronic hepatitis B patients will remain for the foreseeable future. Since current treatments rarely induce permanent viral control and thus need to be given in perpetuity, new therapeutic approaches leading to full viral eradication or at least functional cure are urgently needed.

For HCV infection, the situation is different, but equally challenging. No prophylactic vaccine is available, but the most recent DAA therapies are extremely effective and cure chronic infection in almost all treated patients [9]. The main challenge will be to make therapies affordable everywhere and to improve local medical infrastructure to allow for diagnosis and then treatment of most patients $[\underline{10}, \underline{11}]$. The difficulties and delays in implementing universal HBV vaccination programs are a clear warning that such complex programs are not easily implemented on a global scale, and we should not expect the worldwide HCV epidemic to be dramatically curbed in the near future. In this situation, HCV vaccines remain an attractive complement to antiviral therapy, especially for areas with limited resources and high HCV prevalence. Additionally, in countries that have started to treat all diagnosed HCV patients, ongoing injection-drug use puts a significant subgroup of patients at risk for new and re-infection [12]. Many countries, including the United States, have seen a dramatic surge of intravenous drug use [13], most notably of heroin. Coincidentally, a wave of new HCV infections among young users has been observed in Massachusetts (1,026 reported cases from 2007-2009) [14] and other jurisdictions in the US [15-17] signaling a dramatic new HCV epidemic. Thus, an effective HCV vaccine remains highly desirable even in the era of DAA therapy. 
Considering this information, it is evident that research efforts aiming to develop HBV immunotherapies and HCV vaccines should remain a high priority. Indeed, interest in HBV research has recently been invigorated, especially within the pharmaceutical industry. For many years, the availability of $\mathrm{HBV}$ vaccines and treatments, despite the evidence for continued high rates of $\mathrm{HBV}$ related morbidity and mortality around the globe, seems to have almost paralyzed funding agencies and industry. During those years, the annual HBV meeting was a small gathering of the most dedicated scientists, as public funding for HBV research remained flat or was even declining from already low levels [18]. Overall, combined NIH funding for HBV and HCV research is less than $5 \%$ of the annual expenditures for HIV (Figure 1). Because only a small fraction of these funds is spent on immunological studies, it is not surprising that the field is lacking the depth and breadth of investigation that would lead to faster progress and the consilience of findings from overlapping studies from different laboratories. Now, the same premature label of "disease of the past" has become attached to HCV infection. It is not uncommon to hear in NIH study sections that HCV research supposedly lacks relevance. At meetings and conferences, we regularly hear the question "what are you going to work on now?" [19]. We think the answer is obvious and we must continue studying the immunology of HBV and HCV until we have successful interventions that will truly diminish the dramatic impact that these 2 viral infections continue to have on millions of people worldwide.

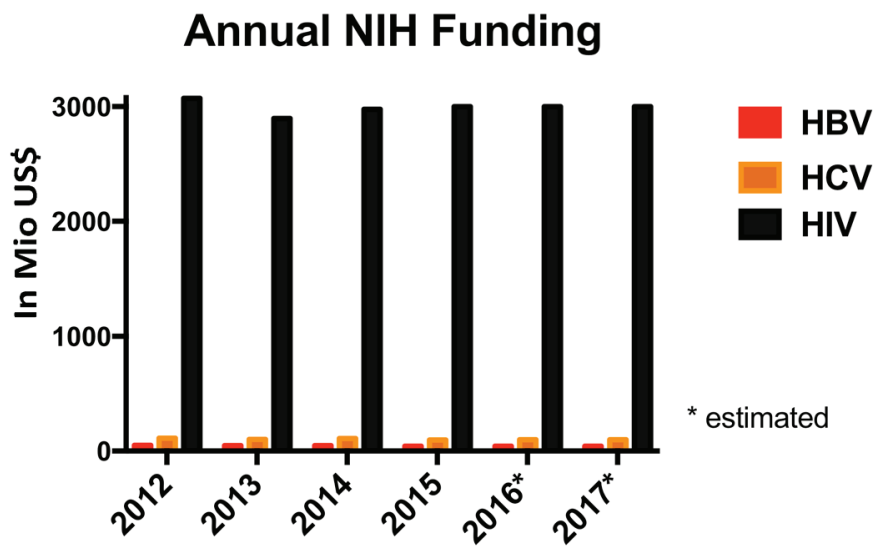

Figure 1: NIH research funding for $\mathrm{HCV}, \mathrm{HBV}$ and $\mathrm{HIV}$ infection. Annual report of NIH funding, expressed as millions of dollars,(US) for research related to HIV (black bars), HCV (orange bars) and HBV (red bars) from 2012 to 2017.

In this review, we will focus on key questions related to the immunological control of HBV and $\mathrm{HCV}$ and outline the current available data. We will also highlight the gaps in our knowledge that we see as critical to be filled to spur the development of effective vaccines and immunotherapies. While some of the challenges and questions are the same for both viruses, key differences in their clinical and virological course, and in the nature of the required immunological interventions, lead to partially different foci of immunological investigation. 


\section{HBV AND HCV: DIFFERENT COURSES OF INFECTION}

HCV typically results in a straightforward and linear clinical, virological, and immunological course of infection that is quite distinct from the much more complicated situation in HBV infection. Once a person becomes infected with $\mathrm{HCV}$, they either develop chronic viremia, or completely resolve the infection, usually within 6 months of exposure [20]. After this decisive phase, virus-host interactions remain relatively stable, and most patients progress on a comparatively linear scale clinically, although at different speeds. The individual trajectory can range from a completely stable scenario with total absence of liver disease, to the development of severe active hepatitis and fibrosis followed by cirrhosis in only a few years. This may occur, for example, with HIV coinfection [20] [21]. However, in most HCV cases, the timespan from infection to severe liver disease is measured in decades, not years. In comparison, HBV infection evolves in a much more complex and dynamic way throughout its entire course, and many of the associated key immunological and virological mechanisms are not completely understood. First, there is an important age factor; as HBV infections in newborns or at a young age mostly result in chronic infection, while almost all adults will control HBV spontaneously [22]. In contrast, age is much less of a determinant for the outcome of HCV infection and younger age at infection is actually associated with a more favorable outcome [23]. Second, it is not quite clear whether full eradication of $\mathrm{HBV}$ is possible as part of its natural history, or whether HBV covalently closed circular DNA (cccDNA) persists in all subjects indefinitely, even in resolved infections with hepatitis B surface antigen (HBsAg) clearance and HBsAg seroconversion. Finally, chronic HBV infection itself is a dynamic and non-linear process, with different stages characterized by different combinations of viral replication levels, antibody (and T cell) response features, and changes in liver disease activity [24]. Understanding to what degree the immune response is responsible for these distinctive features of HBV infection, or whether it only responds to them, will be critical for designing successful immunotherapeutic interventions.

\section{HBV: AGE AND IMMUNE RESPONSE}

The age-related difference in the clinical outcome of acute HBV infection is striking [25]. In adults, at least $95 \%$ of primary infections result in seroconversion to hepatitis B surface antibody (anti-HBs) and long-lasting immunity against reinfection [26]. In contrast, $>90 \%$ of newborns and $30 \%$ of children aged 1-5 years fail to resolve HBV and develop chronic infection [22, 27] (Figure 2). Chronic HBV infection in children is initially characterized by high viral loads (HBV-DNA) in the absence of clinical or biochemical signs of liver disease. Because HBV is not cytopathic by itself and the cellular immune response is thought to be the key mediator of liver inflammation in HBV infection, this has been interpreted as evidence that an immunotolerant state is key to HBV persistence, and maintained for many years post infection [28, 29]. However, at present our understanding of the early host virus interactions in newborns or young children exposed to HBV is still extremely limited, and therefore the exact gaps in the anti-HBV immune response that enable chronicity have not been well defined. The most specific hypothesis stems from a study in a mouse model of HBV infection, which suggests that maternal HBV e antigen induces PD-L1 expression and altered polarization in the macrophages of the offspring, leading to direct impairment of the $\mathrm{HBV}$-specific $\mathrm{CD} 8$ response[30]. It remains to be seen how these findings translate to human HBV infection. Similarly, it remains unclear whether the subsequent "immunotolerant phase" is in fact characterized by an absence of adaptive immune responses or by the presence of immune responses that are unable to mediate both viral control and hepat- 
ic damage. In that context a recent study on CD8 T-cell responses had quite surprising results, suggesting that the weakness of inflammatory activity during the immunotolerant phase cannot be equated with the absence of HBV-specific T-cell responses [31]. The HBV-specific CD8 T-cell responses that were detected in children and young adults without signs of active liver disease unexpectedly displayed better functionality in terms of proliferation and cytokine secretion. Other studies were less successful in identifying T-cell responses in the immunotolerant phase [ $\underline{32}, \underline{33}]$, so at this point it seems premature to close this chapter of investigation.

A comprehensive assessment of the global immune response against the development and evolution of HBV infection in children will be critical to define the determinants of protection as well as HBV viral persistence, and to better understand the immunological foundation from which later phases of chronic infection emerge. There are reasons for the sparseness of relevant data regarding childhood infection, for example, newborns identified to be at risk for infection can be successfully protected through concurrent active and passive immunization. In addition, only minimal amounts of blood can be drawn for analysis to investigate the sporadic infections in young children that still can be identified [34]. Nevertheless, newer technologies allowing comprehensive analysis of even single immune cells $[\underline{35}, \underline{36}]$ should allow us to finally decipher the immunological correlates of viral control, viral persistence, and the actual immune status during what we call the immunotolerant phase.

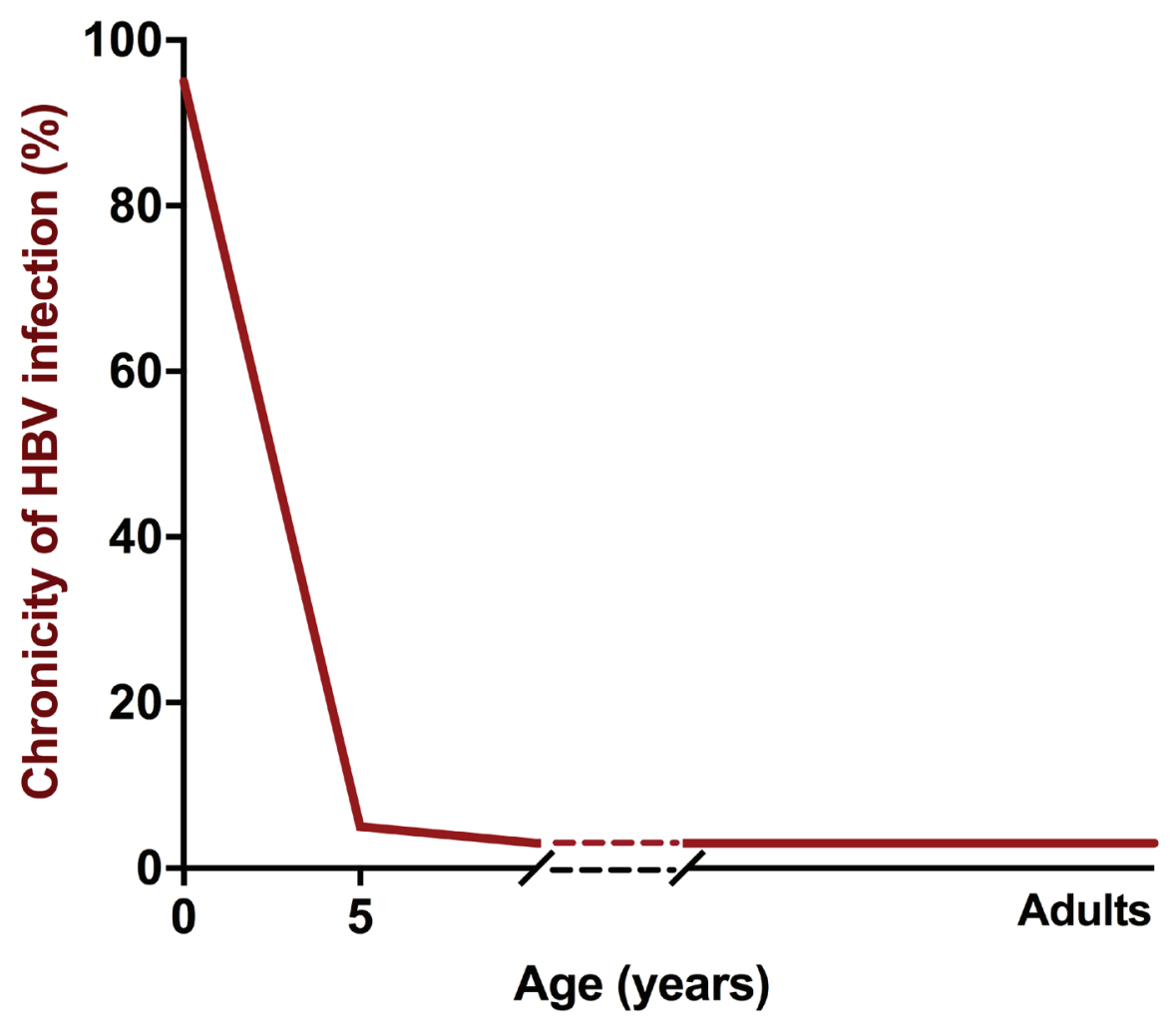

Figure 2: Risk of chronic Hepatitis B related to age. The risk of developing chronic HBV infection is strikingly age dependent. 


\section{WHAT IS "RESOLVED" ANTI-HBS POSITIVE HBV INFECTION? WHAT MEDIATES HBV RESOLUTION?}

Clearance of HBsAg and the consecutive development of anti-HBs are the established hallmarks of HBV resolution [37]. This is regularly observed in adults with primary infection [38], but can also occur spontaneously on rare occasions, even after many years of chronic hepatitis B infection [24]. It is also the desired, though infrequent, outcome of current antiviral therapies [39]. However, what is referred to as resolved infection is not necessarily equivalent to the complete viral clearance observed in HCV infection. This is evidenced by small flares of HBV viremia that can sometimes be observed in people who have a positive test for anti-HBs [40]. In addition active HBV replication can recur during episodes of immune suppression, for example in patients undergoing ablative chemotherapies or immunomodulatory treatments with drugs like rituximab, although only in a small subgroup of patients $[\underline{41}, \underline{42}]$. Underlying this phenomenon is the long-term persistence of cccDNA, the intracellular intermediate replication form of $\mathrm{HBV}$ [43]. The presence of cccDNA can only be reliably detected by analyzing liver tissue [44], which cannot routinely be sampled and is especially unlikely to be obtained from people without active liver disease. Therefore, we do not know if cccDNA persistence is universal in patients with resolved infection, or whether there are cases in which the immune response has truly eliminated all traces of HBV. This is a fundamental question to answer, because it will tell us whether immunotherapies have the potential to achieve complete HBV eradication, or whether a functional cure is the most optimistic scenario for these therapies. If both scenarios do co-exist, there might be differences in the immune mechanisms mediating full clearance versus functional cure.

The fact that not only general immunosuppression but also specific immunomodulatory drugs, lead to loss of HBV control offers the opportunity to elucidate which immune mechanisms are the key mediators of HBV control. In particular, studies of the immunomodulators with more targeted functions might be instructive; however, their modes of action are more complex than is often appreciated. For example, rituximab is a monoclonal antibody targeting the CD20 antigen expressed on $\mathrm{B}$ cells, thus diminishing antibody production [45]. However, rituximab treatment also impairs CD4 T cells and alters CD8 T-cell distribution, which also could enable HBV recurrences $[\underline{42}, \underline{46}]$. Nevertheless, analyzing the detailed effect of such drugs on virus-specific immune responses targeting HBV and other viruses will reveal important aspects of exactly how immunity is conferred .

While the exact contributions of many arms of the immune system in controlling HBV have not yet been defined, there is reasonably strong data that vigorous and multi-specific CD4 and CD8 T-cell responses are necessary. Studies of CD4 and CD8 T-cell depletion in chimpanzees have been shown to enable chronic infection [47, 48], while functional T-cell responses are associated with HBsAg clearance $[\underline{49}, \underline{50}]$. Nevertheless, we need more data on the exact immunological requirements for achieving control in acute $\mathrm{HBV}$ infection and how subsequent long-term control is maintained. A recent study from Carlo Ferrari's group made a detailed analysis of HLA tetramer+ CD8 T cells from acute and chronic infection at the molecular level, and they found significant mitochondrial dysfunction in HBV-specific CD8 T cells during chronicity. This exemplifies the kind of immunological analysis that is now feasible and needed [51]. 


\section{THE IMMUNE RESPONSE IN NATURAL AND TREATMENT-ASSOCIATED TRANSITIONS BETWEEN DIFFER- ENT STAGES OF CHRONIC HBV INFECTION: DRIVER OR PASSENGER?}

Chronic HBV infection evolves in distinct stages that are broadly characterized by a combination of different levels of viral replication and liver disease activity, together with changes in HBV antibody profiles (Figure 3). The typical course of HBV disease after childhood infection, which often evolves over decades, ranges from the asymptomatic immunotolerant phase, with high viral replication and no significant liver inflammation and fibrosis, to the immune-reactive phase with lower viral replication but active inflammation, and finally to the inactive phase with low viral loads and no or minimal disease [52]. This later inactive phase can sometimes be followed by reactivation of disease activity in a variety of circumstances [53-55]. It should be noted, however, that this schematic sequential evolution of chronic HBV infection is not exactly replicated in every patient, as real-life infection, not surprisingly, comes in many shades of grey. Each of these distinct clinical phases and their transitions, and also those patients with unusual clinical features deviating from the classical course of HBV infection, have the potential to teach us about distinct modes of interaction between the virus and the immune system.

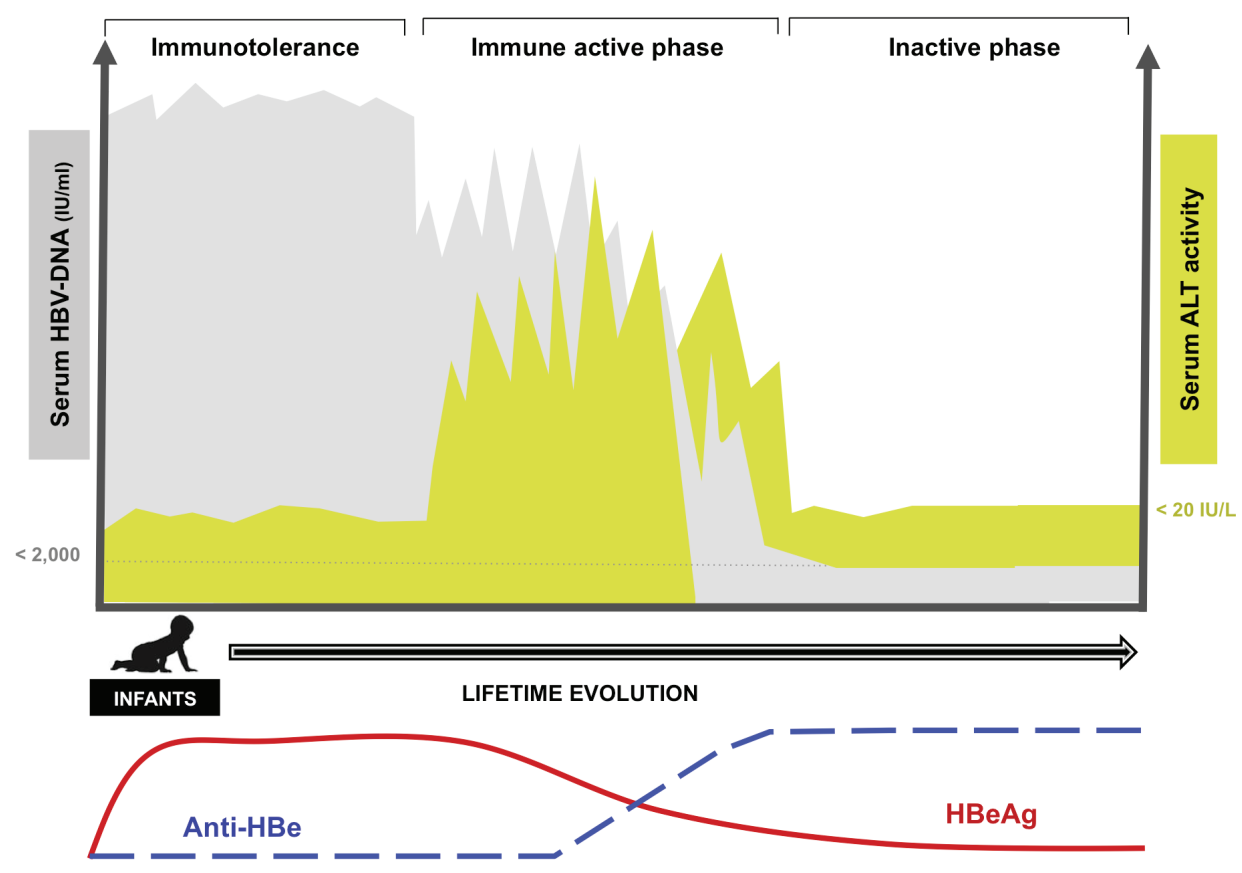

Figure 3: Natural evolution of chronic HBV infection in infants. The long-term course of chronic hepatitis B infection after infant exposure can be typically described in 3 different phases, characterized by different patterns of ALT elevation (green), HBV-DNA levels (grey), and the presence of HBe-Ag (redline) or anti-HBe (blue).

We have already discussed the immunotolerant phase; however, at the end of this phase clearly something remarkable must be happening, because after many years of uncontrolled infection patients spontaneously achieve viral control and also develop liver disease [ㄷ6]. This seems to be 
a dynamic process, as significant fluctuations in both viral load and ALT can be observed in this period, until both viral load and liver-disease activity decline together with HBe seroconversion, during the transition to the inactive carrier state.

What initiates and drives these transitions? Thus far we have mostly circumstantial evidence. In some, but not all patients, ALT flares precede HBe seroconversion, potentially suggesting increased or functionally altered CD8 T-cell activity. Early puberty onset is associated with early seroconversion in both male and female children $[\underline{57}, \underline{58}]$, suggesting a hormonal trigger for the change in immunological control. Indicating a more specific immunological mechanism, certain HLA class I and class II alleles (HLA-B61 and HLA-DQB1*0503) [89-61], and also IL10 and IL12 polymorphisms associated with altered levels of circulating cytokines, have been linked to earlier HBeAg seroconversion in long-term studies from childhood to adult life $[\underline{62}, \underline{63}]$. At this point we are a long way from identifying the exact immunological changes during the transitions from one clinical phase of HBV infection to another, and from understanding underlying causalities. This is also true for the occasional cases of spontaneous reactivation of active HBV-related liver disease in the absence of immunosuppressive therapies $[\underline{64}, \underline{65}]$. Investigating these phenomena in humans is rather challenging, not least because of the slow and unpredictable evolution of HBV infection, and so this work does not fit well with the scientific funding cycle. The establishment of high quality, well-defined, and appropriately sampled clinical cohorts are the sound foundation of any high quality human research, but is labor and time intensive and rarely rewarded by scientific review panels. The resulting lack of support for cohort building as the basis for translational bench research has hampered both HBV and HCV research, especially given the lack of suitable animal models for immunological studies related to these viruses.

Analyses of immunological changes during HBV therapy are the logical extension of studies defining the immune response during the natural history of HBV infection. Since immunotherapies will almost certainly not be fully effective on their own, they will most likely be given in conjunction with antiviral treatments to reduce the viral burden, because at least some viral escape mechanisms, such as T-cell exhaustion, are the direct consequence of antigen load [66]. Indeed, increases in functionality and frequency of HBV-specific CD4 and CD8 T cells have been observed during anti-HBV therapy $[\underline{67}, \underline{68}]$, although the improved responses are not effective enough to maintain viral control after cessation of therapy in most cases [39]. One obvious strategy in this context would be the addition of therapies restoring T-cell activity by blockade of T-cell inhibitory pathways, such as the PD-1/PD-L1 axis. This approach has been shown to be effective for resuscitating T-cell responses targeting human cancer $[\underline{69}, \underline{70}]$, and also to some degree HCV infection [71]. Many other T-cell inhibitory pathways have been discovered over the last decade, mostly in animal models of cancer and infection, and often their blockade had not only additive but also synergistic results for T-cell recovery [72-75]. On the other hand, recent data indicate that sometimes $\mathrm{T}$ cells that have been exhausted by inhibitory pathways for a very long time, such as in most cases of chronic HBV infection, might have epigenetic alterations, which could severely limit the potential for immune reconstitution by these mechanisms $[\underline{76}, \underline{77}]$. Therefore, we should continue to explore additional, HBV-specific immune inhibitory mechanisms that could be equally or better suited for HBV immunotherapies. In addition, we need to consider that for $\mathrm{HBV}$ infection there is always the concern that strong invigoration of the immune response might have undesirable consequences, most notably ALT flares or even severe liver damage [22]. This underscores the primary need for understanding the immunological mechanisms of viral control 
and liver damage during the natural history of HBV infection, followed by studies on how antiviral therapy could shift the balance between host and virus towards a situation more suitable to immunological interventions during the different phases of the infection. Only with this knowledge will it be feasible to rationally design immunotherapeutic interventions that can effectively push the immune response towards a profile associated with viral control and not liver injury, an immune profile that we know exists in the many individuals that have achieved sustained viral resolution.

\section{HCV INFECTION}

$\mathrm{HCV}$ infection is unique among chronic viral infections in humans because a significant proportion of infected people, estimated to be $20 \%$ to $30 \%$, can fully clear viremia spontaneously [20]. Typically, HCV clearance is achieved only within 6 months of infection, and after this spontaneous clearance, people who are later re-exposed to HCV, have a high likelihood of terminating viremia again $[\underline{78}, \underline{79}]$. These observations support the idea that at least protection from chronic infection is highly plausible for HCV infection. However, we do not know if sterilizing immunity can be achieved by vaccination, nor what kind of vaccine-induced immune response would be required to assure protection from chronicity.

\section{CAN HCV VIRAL DIVERSITY BE OVERCOME?}

The imposing diversity of circulating HCV strains is the most challenging hurdle for effective vaccination. The HCV is a single-stranded, positive sense, RNA virus of approximately 9,600 nucleotides in a coding region that contains 1 large open reading frame flanked by non-translated regions at the $5^{\prime}$ and $3^{\prime}$ ends [ $\left.\underline{80}\right]$. Due to the lack of a proof-reading function, its RNA-polymerase has a high error rate, estimated at $10-{ }^{4}$ substitutions per site and round of replication, among the highest for RNA viruses including retroviruses [81]. Together with its high replication rate (approximately $10^{12}$ virions per day) [르 ] and the selective pressure exerted by the host immune system, this leads to the constant emergence of new HCV variants. The diversity starts within the host, as HCV infection is characterized by the co-existence of a swarm of closely related viruses, called viral quasispecies, at any given time. At the population level, viral diversity is much greater than that of other variable viruses, such as HIV and HBV (Figure 4), which is the result of HCV not only being highly variable but also having been present in humans for a very long time. We can now differentiate at least 7 different HCV genotypes and many more subtypes, with genetic variability between genotypes ranging from $31 \%-33 \%$ on the nucleotide level [ $\underline{83}]$. The genotypes of HCV show regional differences, examples being genotype 1 and more recently genotype 3 , most frequently found in the US and Europe and genotype 4 being dominant in Egypt [우, $\underline{84}$ ]. This heterogeneity of infecting viruses makes development of a universal HCV vaccine extremely challenging. Even genotype specific vaccines would not be trivial to design, considering that the observed diversity even within HCV subtypes is as high as that of all the clades of HIV-1 group $\mathrm{M}$. One suggestion to overcome this obstacle has been to use consensus sequences as immunogens to avoid inclusion of sequences that are already adapted to escape human immune responses, which would be the case for HCV strains isolated from infected patients $[\underline{85}, \underline{86}]$. Another possibility is the use of mosaic sequences that can induce responses against multiple viral variants $[\underline{87}, \underline{88}]$. There is an ongoing clinical trial using an HCV T-cell vaccine based on the complete non-structural region of a patient-derived genotype $1 \mathrm{~b}$ sequence. The participants are injection 
drug users and are at high risk for HCV infection [89]; this study should reveal important insights into the impact of HCV variability on vaccine efficacy.

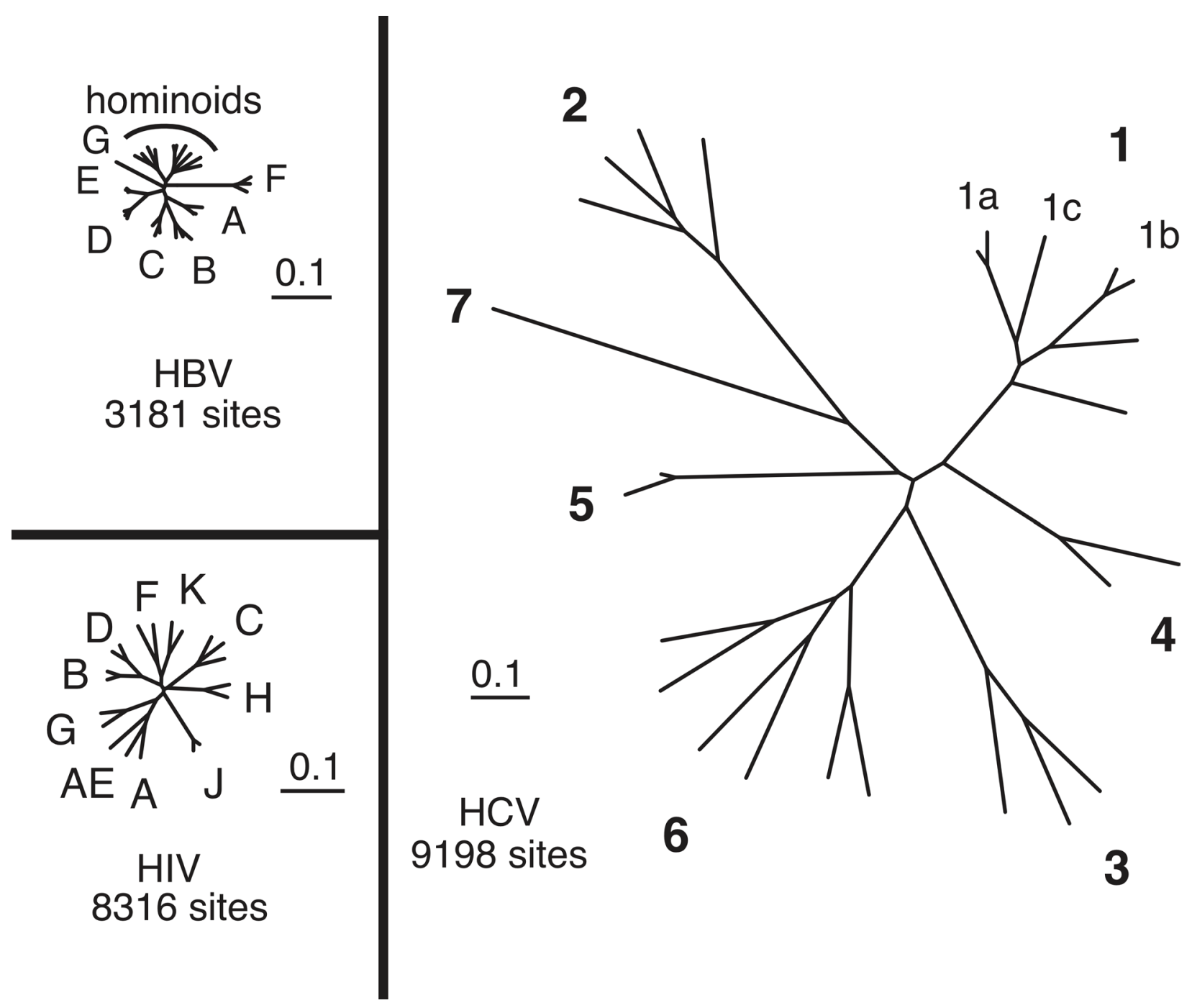

Figure 4: Viral diversity of three viruses: HIV, HBV amnd HCV. Phylogenetic trees for hepatitis B virus (HBV), human immunodeficiency virus (HIV), and hepatitis C virus (HCV) shown to the same scale in terms of nucleotide genetic distance, based on full-length genome nucleotide sequences.Sequences of representative strains for major genotypes were obtained from GenBank and aligned using ClustalX with minor manual adjustment, and then sites containing gaps were removed, resulting in an alignment of 3181 sites for HBV, 8316 sites for HIV, and 9198 sites for HCV. Maximum likelihood trees were inferred using PAUP $^{\star}$ version $4 \mathrm{~b} 10$, with the model $(\mathrm{GTR}+\mathrm{I}+\mathrm{G}$ in all three cases) and parameters selected by ModelTest 3.7 using the AIC criterion.

Reproduced with friendly permission from Dr. Stuart Ray.

(Figure 156-4 from Ray SC and Thomas DL. In: Bennett JE, Dolin R, and Blaser MJ (eds). Mandell, Douglas, and Bennett's Principles and Practices of Infectious Diseases. 8th ed (updated). Churchill Livingstone Elsevier; 2015:1904-1927). 


\section{IS STERILIZING IMMUNITY POSSIBLE?}

Antibody mediated sterilizing immunity is the classic mechanism of protection used by traditional antiviral vaccines $[\underline{90}, \underline{91}]$. However, it remains an open question whether sterilizing immunity is a feasible goal for $\mathrm{HCV}$ vaccines. Humans or chimpanzees, who have previously resolved $\mathrm{HCV}$ infection spontaneously, produce neutralizing antibodies, yet reinfection even with closely related viral strains can be observed. On the other hand, it has been reported that some chimpanzees were at least protected from a second homologous challenge $[92,93]$, indicating that failure of protection is not necessarily caused by an inability to prevent infection through neutralization, but rather by the high viral diversity of HCV as already described. This is not surprising, since the viral envelope regions most accessible for neutralization also contain some of the most variable regions of HCV $[94,95]$, as a direct consequence of antibody-mediated immune pressure. Nevertheless, several highly cross-reactive antibodies targeting highly conserved HCV epitopes have been identified [96], and together with antibody modifications overcoming neutralization resistance their potential in a prophylactic vaccine conferring sterilizing immunity should be explored.

\section{WHAT KIND OF IMMUNE RESPONSE WILL RELIABLY PROTECT FROM CHRONIC INFECTION?}

Given the uncertain potential for a vaccine inducing sterilizing immunity, a second line of defense should be part of the strategy to protect against chronic hepatitis $\mathrm{C}$. The dichotomy of natural $\mathrm{HCV}$ outcome, with $20 \%$ to $30 \%$ of infected people clearing viremia spontaneously [20], is proof that $\mathrm{HCV}$ can be immunologically controlled after infection. The potential for a vaccine to at least provide protection from chronic infection is further underscored by the fact that reinfection in people and chimpanzees who have previously cleared HCV is self-limited in most cases [78], with lower peak viremia and more rapid viral clearance. However, we do not know what kind of immune response is essential for viral control and what kind of vaccine-induced memory response would ensure protection on exposure.

With regard to protective immunity in established HCV infection, the most convincing data support an absolute requirement for HCV-specific CD4 as well as CD8 T-cell responses. Depletion of either cell type was associated with persistent infection in the chimpanzee model of $\mathrm{HCV}$ [97]. In addition, the emergence of HCV-specific CD8 T cells coincides with signs of viral control in both humans and chimpanzees $[98,99]$, whereas early defects in the proliferative capacity of HCV-specific CD4 T cells are the universally accepted hallmark of viral persistence [100-102]. It is much less obvious what quality or repertoire of T-cell response needs to be induced. One often reads that breadth and magnitude of the responses are critical, but in our opinion this is not fully supported by the experimental data. There is no doubt that with established HCV clearance or persistence, we observe much weaker and usually more narrow T-cell responses in patients with chronic infection. Nevertheless, studies at early time points in acute infection support the hypothesis that broadly directed and vigorous CD4 and CD8 T-cell responses are primed in most patients, and that maintenance of the responses is the most critical difference between self-limited and chronic infection [103-105]. Differences in viral control also manifest in the expression of inhibitory receptors such as PD-1 on T cells $[106,107]$ and other viral escape mechanisms, such as the occurrence of viral escape variants [ $\underline{85}$ ]. However, it is not clear whether these differences are the cause or consequence of differences in viral control, and it seems quite possible that additional early events initiate the distinct fate of the T-cell response in different outcomes of infection. 
Very few studies of acute hepatitis $\mathrm{C}$ actually investigate the early immune response, before viral control or viral persistence are established. This is not surprising, given the usually unspecific symptoms of acute infection and the organizational challenges to identify and recruit subjects immediately after infection. Nevertheless, such studies are critical for understanding not only the consequences of distinct virological outcomes but also the drivers of immune control and failure.

Despite significant gaps in understanding of the immune determinants of HCV control, it seems a reasonable assumption that induction of a broadly directed response by both CD 4 and CD8 T cells will be beneficial, if only because it will allow some redundancy when confronted with viral strains containing T-cell epitope variants. Careful analysis of ongoing vaccine trials should answer the question of whether $\mathrm{T}$ cells with a specific transcriptional profile and different cell subpopulations, especially $\mathrm{T}$ helper cells, are critical for protection, or whether a more rapid response time of any vaccine-induced memory $\mathrm{T}$ cells provides a sufficient advantage for the host. Additional valuable insights will come from analyzing patients that experience reinfection after previous clearance of HCV.

Antibodies specific for HCV might also contribute to HCV control after infection has been established, but the possible extent of their contribution has not been well defined and remains somewhat controversial. Clearly, HCV-specific antibodies do not seem an absolute requirement for spontaneous clearance of HCV, as self-limited infections have been observed in patients with antibody deficiencies, but they could still contribute to viral control after infection. Indeed, with the more recent introduction of neutralizing antibody assays for HCV we have seen good evidence suggesting a protective role for neutralizing antibodies in at least a subgroup of patients [91, 108]. In addition, non-neutralizing antibodies might contribute to viral control through virus-specific mediation of antibody-dependent cell-mediated cytotoxicity (ADCC) and other innate immune functions [109]. It seems likely that there is more than one immunological path to HCV clearance. If a vaccine can induce many different potential mediators of $\mathrm{HCV}$ control, it will be much for difficult for the virus to escape immune surveillance.

\section{HBV, HCV, AND THE LIVER}

Understanding how immunity unfolds and is regulated within the liver as the site of infection will be critical for developing HBV immunotherapies as well as HCV vaccines. It has been well established from animal models, that the immunological environment of different tissues has a major impact on the immune response at the site of infection. In addition, the liver is a unique immunological organ, for both its tissue architecture and its role as the entry gate for molecules taken up in the gut [110]. Early studies on both HBV and HCV immunology often had to rely on liver biopsies, because immunological assays at the time were only capable of detecting specific T cells from the liver where they are present in much higher frequencies. Subsequently, more sensitive techniques have allowed analysis of virus-specific T cells from the blood, allowing for studies in many more subjects and at multiple time points. Despite this unquestionable improvement, some important dimensions of the immune response against hepatotropic viruses were also lost. Several groups continued to investigate intrahepatic T cells, resulting in important insights $[\underline{111}, \underline{112}]$, but only recently have we obtained the necessary tools to comprehensively study very small numbers of cells, even single cells $[\underline{113}, \underline{114}]$, and in great detail at the same time. While clinical biopsies have become much less important and frequent in both HBV and HCV infection, the ability 
to analyze very small populations of cells has enabled the use of fine-needle aspirates of the liver, which can be performed serially and outside the context of a clinically required biopsy [115]. We expect that this will lead to a completely new assessment of virus-host interactions directly at the site of infection. These kinds of studies should also allow an appreciation of intrahepatic interactions between different pathogens that can significantly alter the local environment, both virologically and immunologically. A prime example is the recent observation that successful therapy of chronic HCV infection using DAAs can be associated with the reactivation of previously controlled HBV $[\underline{116}, \underline{117}]$. Whether this was caused by HCV eradication opening up replicative space in the hepatocyte population, or by changes in HCV-induced innate or adaptive immunity that had helped to control HBV, is not yet clear, but studies in such scenarios could contribute greatly to our understanding of complex immune surveillance networks at the site of infection.

\section{SUMMARY}

The battle against both HBV and HCV infection would greatly benefit from having novel immunological weapons in its arsenal. In particular, we need therapeutic approaches mediating functional cure in $\mathrm{HBV}$ infection and prophylactic vaccines protecting from the development of chronic infection for HCV. In order to develop such interventions, we need to better understand the complex host and virus interactions in these viral infections and their relationship to viral control and viral persistence mechanisms. Some key questions overlap between the 2 viruses, most notably regarding the essence of what constitutes effective immunity and the characteristics of an immune response unfolding within the liver. However, each virus also poses a distinct set of questions related to their rather different clinical course and viral features, and because of the different nature of the desired immunological intervention. Recent technological breakthroughs have opened unprecedented opportunities for human immunology research, and with adequate funding scientific and medical breakthroughs should follow.

\section{POTENTIAL CONFLICTS OF INTEREST}

The authors do not have a conflict to declare.

\section{FINANCIAL SUPPORT}

National Institutes of Health (NIH) grant U19 AI082630, NIH grant U19 AI066345 and NIH grant R01 AI105035 to GML

\section{REFERENCES}

1. WHO. Global Health Sector Strategy on Viral Hepatitis 2016-2021. Towards Ending Viral Hepatitis 2016 [updated June 2016]. WHO/HIV/2016.06]. Available from: http:// www.who.int/hepatitis/strategy2016-2021/ghss-hep/en/.

2. The Immunological basis for immunization series [Internet]. 2011. Available from: http://www.who.int/immunization/documents/ISBN_978_92_4_150475_1/en/.

3. Ott JJ, Stevens GA, Groeger J, Wiersma ST. Global epidemiology of hepatitis B virus infection: new estimates of age-specific HBsAg seroprevalence and endemicity. Vaccine. 2012;30(12):2212-9. PubMed PMID: 22273662. doi: 10.1016/j.vaccine.2011.12.116 
4. Stephenne J. Contribution to hepatitis B prevention. Vaccine. 1992;10(13):900-3. PubMed PMID: 1471409.

5. Lok E-KTaAS. Epidemiology, transmission, and prevention of hepatitis B virus infection UptoDate2016 [updated February 2017; cited 2016]. Available from: https://www. uptodate.com/contents/epidemiology-transmission-and-prevention-of-hepatitis-b-virus-infection.

6. Perrillo R. Invited Commentary: Screening for hepatitis B in the immigrant population and individuals who are in need of immunosuppressive drug therapy. Proc (Bayl Univ Med Cent). 2015;28(4):443-4. PubMed PMID: 26424936. Pubmed Central PMCID: PMC4569219.

7. WHO. Immunization coverage. WHO, 2016 september 2016. Report No.

8. Infection IoMUCotPaCoVH. Hepatitis and Liver Cancer: A National Strategy for Prevention and Control of Hepatitis B and C. In: Colvin HM, Mitchell AE, editors. Hepatitis and Liver Cancer: A National Strategy for Prevention and Control of Hepatitis B and C. Washington (DC) 2010.

9. Farnik H, Zeuzem S. New antiviral therapies in the management of HCV infection. Antivir Ther. 2012;17(5):771-83. PubMed PMID: 22626842. doi: 10.3851/IMP2127

10. Graham CS, Swan T. A path to eradication of hepatitis C in low- and middle-income countries. Antiviral Res. 2015;119:89-96. PubMed PMID: 25615583. doi: 10.1016/j. antiviral.2015.01.004

11. Hesamizadeh K, Sharafi H, Rezaee-Zavareh MS, Behnava B, Alavian SM. Next Steps Toward Eradication of Hepatitis C in the Era of Direct Acting Antivirals. Hepat Mon. 2016;16(4):e37089. PubMed PMID: 27275164. Pubmed Central PMCID: PMC4893415. doi: 10.5812/hepatmon.37089

12. Scott N, McBryde E, Vickerman P, Martin NK, Stone J, Drummer H, Hellard M. The role of a hepatitis $\mathrm{C}$ virus vaccine: modelling the benefits alongside direct-acting antiviral treatments. BMC Med. 2015;13:198. PubMed PMID: 26289050. Pubmed Central PMCID: PMC4546023. doi: 10.1186/s12916-015-0440-2

13. Suryaprasad AG, White JZ, Xu F, Eichler BA, Hamilton J, Patel A, Hamdounia SB, Church DR, Barton K, Fisher C, Macomber K, Stanley M, Guilfoyle SM, Sweet K, Liu S, Iqbal K, Tohme R, Sharapov U, Kupronis BA, Ward JW, Holmberg SD. Emerging epidemic of hepatitis $\mathrm{C}$ virus infections among young nonurban persons who inject drugs in the United States, 2006-2012. Clin Infect Dis. 2014;59(10):1411-9. PubMed PMID: 25114031. doi: 10.1093/cid/ciu643

14. Centers for Disease C, Prevention. Hepatitis $C$ virus infection among adolescents and young adults:Massachusetts, 2002-2009. MMWR Morb Mortal Wkly Rep. 2011;60(17):537-41. PubMed PMID: 21544042.

15. Klevens RM, Hu DJ, Jiles R, Holmberg SD. Evolving epidemiology of hepatitis C virus in the United States. Clin Infect Dis. 2012;55 Suppl 1:S3-9. PubMed PMID: 22715211. doi: $10.1093 / \mathrm{cid} / \mathrm{cis} 393$ 
16. Centers for Disease C, Prevention. Notes from the field : hepatitis C virus infections among young adults--rural Wisconsin, 2010. MMWR Morb Mortal Wkly Rep. 2012;61(19):358. PubMed PMID: 22592276.

17. Kim AY, Onofrey S, Church DR. An epidemiologic update on hepatitis C infection in persons living with or at risk of HIV infection. J Infect Dis. 2013;207 Suppl 1:S1-6. PubMed PMID: 23390299. Pubmed Central PMCID: PMC3565593. doi: 10.1093/infdis/jis927

18. NIH. Estimates of Funding for Various Research, Condition, and Disease Categories (RCDC) 2016 [2017]. Available from: https://report.nih.gov/categorical_spending. aspx.

19. Rosen HR. "Hep C, where art thou": What are the remaining (fundable) questions in hepatitis C virus research? Hepatology. 2017;65(1):341-9. PubMed PMID: 27640881. doi: 10.1002/hep.28848

20. Lauer GM, Walker BD. Hepatitis C virus infection. N Engl J Med. 2001;345(1):41-52. PubMed PMID: 11439948.

21. Graham CS, Baden LR, Yu E, Mrus JM, Carnie J, Heeren T, Koziel MJ. Influence of human immunodeficiency virus infection on the course of hepatitis $\mathrm{C}$ virus infection: a meta-analysis. Clin Infect Dis. 2001;33(4):562-9. PubMed PMID: 11462196.

22. Ganem D, Prince AM. Hepatitis B virus infection--natural history and clinical consequences. N Engl J Med. 2004;350(11):1118-29. PubMed PMID: 15014185. doi: 10.1056/NEJMra031087

23. Chen SL, Morgan TR. The natural history of hepatitis $\mathrm{C}$ virus (HCV) infection. Int J Med Sci. 2006;3(2):47-52. PubMed PMID: 16614742. Pubmed Central PMCID: PMC1415841.

24. Wu JF, Chang MH. Natural history of chronic hepatitis B virus infection from infancy to adult life - the mechanism of inflammation triggering and long-term impacts. J Biomed Sci. 2015;22:92. PubMed PMID: 26487087. Pubmed Central PMCID: PMC4618235. doi: 10.1186/s12929-015-0199-y

25. Chou HH, Chien WH, Wu LL, Cheng CH, Chung CH, Horng JH, Ni YH, Tseng HT, Wu D, Lu X, Wang HY, Chen PJ, Chen DS. Age-related immune clearance of hepatitis $B$ virus infection requires the establishment of gut microbiota. Proc Natl Acad Sci U S A. 2015;112(7):2175-80. PubMed PMID: 25646429. Pubmed Central PMCID: PMC4343154. doi: 10.1073/pnas.1424775112

26. Taylor BC, Yuan JM, Shamliyan TA, Shaukat A, Kane RL, Wilt TJ. Clinical outcomes in adults with chronic hepatitis $B$ in association with patient and viral characteristics: A systematic review of evidence. Hepatology. 2009;49(5 Suppl):S85-95. PubMed PMID: 19399797. doi: 10.1002/hep.22929

27. Liang TJ. Hepatitis B: the virus and disease. Hepatology. 2009;49(5 Suppl):S13-21. PubMed PMID: 19399811. Pubmed Central PMCID: PMC2809016. doi: 10.1002/ hep. 22881 
28. Milich DR, Jones JE, Hughes JL, Price J, Raney AK, McLachlan A. Is a function of the secreted hepatitis B e antigen to induce immunologic tolerance in utero? Proc Natl Acad Sci U S A. 1990;87(17):6599-603. PubMed PMID: 2395863. Pubmed Central PMCID: PMC54584.

29. Milich DR, Jones J, Hughes J, Maruyama T. Role of T-cell tolerance in the persistence of hepatitis B virus infection. J Immunother Emphasis Tumor Immunol. 1993;14(3):226-33. PubMed PMID: 8297904.

30. Tian Y, Kuo CF, Akbari O, Ou JH. Maternal-Derived Hepatitis B Virus e Antigen Alters Macrophage Function in Offspring to Drive Viral Persistence after Vertical Transmission. Immunity. 2016;44(5):1204-14. PubMed PMID: 27156385. Pubmed Central PMCID: PMC4871724. doi: 10.1016/j.immuni.2016.04.008

31. Bertoletti A, Kennedy PT. The immune tolerant phase of chronic HBV infection: new perspectives on an old concept. Cell Mol Immunol. 2015;12(3):258-63. PubMed PMID: 25176526. Pubmed Central PMCID: PMC4654319. doi: 10.1038/cmi.2014.79

32. Publicover J, Goodsell A, Nishimura S, Vilarinho S, Wang ZE, Avanesyan L, Spolski $\mathrm{R}$, Leonard WJ, Cooper S, Baron JL. IL-21 is pivotal in determining age-dependent effectiveness of immune responses in a mouse model of human hepatitis B. J Clin Invest. 2011;121(3):1154-62. PubMed PMID: 21393863. Pubmed Central PMCID: PMC3049376. doi: 10.1172/JCI44198

33. Tran TT. Immune tolerant hepatitis B: a clinical dilemma. Gastroenterology \& hepatology. 2011;7(8):511-6. PubMed PMID: 22298987. Pubmed Central PMCID: 3264935.

34. Centers for Disease C. Immunization Schedules for Infants and Children. 2017.

35. Shalek AK, Satija R, Shuga J, Trombetta JJ, Gennert D, Lu D, Chen P, Gertner RS, Gaublomme JT, Yosef N, Schwartz S, Fowler B, Weaver S, Wang J, Wang X, Ding R, Raychowdhury R, Friedman N, Hacohen N, Park H, May AP, Regev A. Single-cell RNA-seq reveals dynamic paracrine control of cellular variation. Nature. 2014;510(7505):363-9. PubMed PMID: 24919153. Pubmed Central PMCID: 4193940. doi: 10.1038/nature13437

36. Lokhande MU, Thimme R, Klenerman P, Semmo N. Methodologies for the Analysis of HCV-Specific CD4(+) T Cells. Frontiers in immunology. 2015;6:57. PubMed PMID: 25767470. Pubmed Central PMCID: 4341113. doi: 10.3389/fimmu.2015.00057

37. Wright TL, Lau JY. Clinical aspects of hepatitis B virus infection. Lancet. 1993;342(8883):1340-4. PubMed PMID: 7694023.

38. Pan CQ, Zhang JX. Natural History and Clinical Consequences of Hepatitis B Virus Infection. International journal of medical sciences. 2005;2(1):36-40. PubMed PMID: 15968338. Pubmed Central PMCID: 1142223.

39. Rehermann B, Bertoletti A. Immunological aspects of antiviral therapy of chronic hepatitis B virus and hepatitis C virus infections. Hepatology. 2015;61(2):712-21. PubMed PMID: 25048716. Pubmed Central PMCID: PMC4575407. doi: 10.1002/ hep. 27323 
40. Rehermann B, Ferrari C, Pasquinelli C, Chisari FV. The hepatitis B virus persists for decades after patients' recovery from acute viral hepatitis despite active maintenance of a cytotoxic T-lymphocyte response. Nat Med. 1996;2(10):1104-8. PubMed PMID: 8837608 .

41. Lok AS, Liang RH, Chiu EK, Wong KL, Chan TK, Todd D. Reactivation of hepatitis B virus replication in patients receiving cytotoxic therapy. Report of a prospective study. Gastroenterology. 1991;100(1):182-8. PubMed PMID: 1983820.

42. Tsutsumi Y, Yamamoto Y, Ito S, Ohigashi H, Shiratori S, Naruse H, Teshima T. Hepatitis $\mathrm{B}$ virus reactivation with a rituximab-containing regimen. World journal of hepatology. 2015;7(21):2344-51. PubMed PMID: 26413224. Pubmed Central PMCID: PMC4577642. doi: 10.4254/wjh.v7.i21.2344

43. Nassal M. HBV cccDNA: viral persistence reservoir and key obstacle for a cure of chronic hepatitis B. Gut. 2015;64(12):1972-84. PubMed PMID: 26048673. doi: 10.1136/gutjnl-2015-309809

44. Morikawa K, Shimazaki T, Takeda R, Izumi T, Umumura M, Sakamoto N. Hepatitis B: progress in understanding chronicity, the innate immune response, and cccDNA protection. Ann Transl Med. 2016;4(18):337. PubMed PMID: 27761441. Pubmed Central PMCID: PMC5066049. doi: 10.21037/atm.2016.08.54

45. Maloney DG, Grillo-Lopez AJ, White CA, Bodkin D, Schilder RJ, Neidhart JA, Janakiraman N, Foon KA, Liles TM, Dallaire BK, Wey K, Royston I, Davis T, Levy R. IDECC2B8 (Rituximab) anti-CD20 monoclonal antibody therapy in patients with relapsed low-grade non-Hodgkin's lymphoma. Blood. 1997;90(6):2188-95. PubMed PMID: 9310469.

46. Misumi I, Whitmire JK. B cell depletion curtails CD4+ T cell memory and reduces protection against disseminating virus infection. J Immunol. 2014;192(4):1597-608. PubMed PMID: 24453250. Pubmed Central PMCID: PMC3925510. doi: 10.4049/jimmunol.1302661

47. Thimme R, Wieland S, Steiger C, Ghrayeb J, Reimann KA, Purcell RH, Chisari FV. CD8(+) T cells mediate viral clearance and disease pathogenesis during acute hepatitis B virus infection. J Virol. 2003;77(1):68-76. PubMed PMID: 12477811. Pubmed Central PMCID: 140637.

48. Asabe S, Wieland SF, Chattopadhyay PK, Roederer M, Engle RE, Purcell RH, Chisari FV. The size of the viral inoculum contributes to the outcome of hepatitis B virus infection. J Virol. 2009;83(19):9652-62. PubMed PMID: 19625407. Pubmed Central PMCID: PMC2748002. doi: 10.1128/JVI.00867-09

49. Penna A, Artini M, Cavalli A, Levrero M, Bertoletti A, Pilli M, Chisari FV, Rehermann B, Del Prete G, Fiaccadori F, Ferrari C. Long-lasting memory T cell responses following self-limited acute hepatitis B. J Clin Invest. 1996;98(5):1185-94. PubMed PMID: 8787682. Pubmed Central PMCID: PMC507541. doi: 10.1172/JCI118902

50. Rehermann B, Lau D, Hoofnagle JH, Chisari FV. Cytotoxic T lymphocyte responsiveness after resolution of chronic hepatitis B virus infection. J Clin Invest. 1996;97(7):1655-65. PubMed PMID: 8601631. Pubmed Central PMCID: PMC507230. doi: 10.1172/JCI118592 
51. Boni C, Fisicaro P, Valdatta C, Amadei B, Di Vincenzo P, Giuberti T, Laccabue D, Zerbini A, Cavalli A, Missale G, Bertoletti A, Ferrari C. Characterization of hepatitis B virus (HBV)-specific T-cell dysfunction in chronic HBV infection. J Virol. 2007;81(8):4215-25. PubMed PMID: 17287266. Pubmed Central PMCID: 1866111. doi: 10.1128/JVI.02844-06

52. Rehermann B, Nascimbeni M. Immunology of hepatitis B virus and hepatitis C virus infection. Nat Rev Immunol. 2005;5(3):215-29. PubMed PMID: 15738952. doi: $10.1038 /$ nri1573

53. Hwang JP, Barbo AG, Perrillo RP. Hepatitis B reactivation during cancer chemotherapy: an international survey of the membership of the American Association for the Study of Liver Diseases. J Viral Hepat. 2015;22(3):346-52. PubMed PMID: 25220947. Pubmed Central PMCID: PMC4833504. doi: 10.1111/jvh.12305

54. Totani H, Kusumoto S, Ishida T, Masuda A, Yoshida T, Ito A, Ri M, Komatsu H, Murakami S, Mizokami M, Ueda R, Niimi A, Inagaki H, Tanaka Y, Iida S. Reactivation of hepatitis B virus (HBV) infection in adult T-cell leukemia-lymphoma patients with resolved HBV infection following systemic chemotherapy. Int J Hematol. 2015;101(4):398-404. PubMed PMID: 25633779. doi: 10.1007/s12185-015-1750-Z

55. Palmore TN, Shah NL, Loomba R, Borg BB, Lopatin U, Feld JJ, Khokhar F, Lutchman G, Kleiner DE, Young NS, Childs R, Barrett AJ, Liang TJ, Hoofnagle JH, Heller T. Reactivation of hepatitis B with reappearance of hepatitis B surface antigen after chemotherapy and immunosuppression. Clin Gastroenterol Hepatol. 2009;7(10):11307. PubMed PMID: 19577007. Pubmed Central PMCID: PMC2779698. doi: 10.1016/j. cgh.2009.06.027

56. Shin EC, Sung PS, Park SH. Immune responses and immunopathology in acute and chronic viral hepatitis. Nat Rev Immunol. 2016;16(8):509-23. PubMed PMID: 27374637. doi: 10.1038/nri.2016.69

57. Wu JF, Tsai WY, Hsu HY, Ni YH, Chen HL, Tsuei DJ, Chang MH. Effect of puberty onset on spontaneous hepatitis B virus e antigen seroconversion in men. Gastroenterology. 2010;138(3):942-8 e1. PubMed PMID: 19962986. doi: 10.1053/j.gastro.2009.11.051

58. Wu JF, Tsai WY, Tung YC, Chen HL, Ni YH, Hsu HY, Chang MH. Effect of menarche onset on the clinical course in females with chronic hepatitis B virus infection. J Pediatr. 2014;165(3):534-8. PubMed PMID: 24973292. doi: 10.1016/j.jpeds.2014.05.049

59. Hohler T, Gerken G, Notghi A, Lubjuhn R, Taheri H, Protzer U, Lohr HF, Schneider PM, Meyer zum Buschenfelde KH, Rittner C. HLA-DRB1*1301 and ${ }^{\star} 1302$ protect against chronic hepatitis B. J Hepatol. 1997;26(3):503-7. PubMed PMID: 9075656.

60. Ahn SH, Han KH, Park JY, Lee CK, Kang SW, Chon CY, Kim YS, Park K, Kim DK, Moon YM. Association between hepatitis B virus infection and HLA-DR type in Korea. Hepatology. 2000;31(6):1371-3. PubMed PMID: 10827165. doi: 10.1053/ jhep.2000.7988

61. Almarri A, Batchelor JR. HLA and hepatitis B infection. Lancet. 1994;344(8931):11945. PubMed PMID: 7934542. 
62. Wu JF, Ni YH, Lin YT, Lee TJ, Hsu SH, Chen HL, Tsuei DJ, Hsu HY, Chang MH. Human interleukin-10 genotypes are associated with different precore/core gene mutation patterns in children with chronic hepatitis B virus infection. J Pediatr. 2011;158(5):808-13. PubMed PMID: 21168854. doi: 10.1016/j.jpeds.2010.11.015

63. Wu JF, Wu TC, Chen CH, Ni YH, Chen HL, Hsu HY, Chang MH. Serum levels of interleukin-10 and interleukin-12 predict early, spontaneous hepatitis B virus e antigen seroconversion. Gastroenterology. 2010;138(1):165-72 e1-3. PubMed PMID: 19782084. doi: 10.1053/j.gastro.2009.09.018

64. Wahle RC, Perez RM, Pereira PF, Oliveira EM, Emori CT, Uehara SN, Silva IS, Silva AE, Ferraz ML. Hepatitis B virus reactivation after treatment for hepatitis $C$ in hemodialysis patients with HBV/HCV coinfection. Braz J Infect Dis. 2015;19(5):533-7. PubMed PMID: 25997784. doi: 10.1016/j.bjid.2015.04.003

65. Loomba R, Liang TJ. Hepatitis B reactivation associated with immune suppressive and biological modifier therapies: current concepts, management strategies and future directions. Gastroenterology. 2017. PubMed PMID: 28219691. doi: 10.1053/j.gastro.2017.02.009

66. Zhang Z, Jin B, Zhang JY, Xu B, Wang H, Shi M, Wherry EJ, Lau GK, Wang FS. Dynamic decrease in PD-1 expression correlates with HBV-specific memory CD8 T-cell development in acute self-limited hepatitis B patients. J Hepatol. 2009;50(6):1163-73. PubMed PMID: 19395117. doi: 10.1016/j.jhep.2009.01.026

67. de Niet A, Stelma F, Jansen L, Sinnige MJ, Remmerswaal EB, Takkenberg RB, Kootstra NA, Reesink HW, van Lier RA, van Leeuwen EM. Restoration of T cell function in chronic hepatitis B patients upon treatment with interferon based combination therapy. J Hepatol. 2016;64(3):539-46. PubMed PMID: 26505119. doi: 10.1016/j. jhep.2015.10.013

68. Godon O, Fontaine H, Kahi S, Meritet JF, Scott-Algara D, Pol S, Michel ML, Bourgine M, group AHs. Immunological and Antiviral Responses After Therapeutic DNA Immunization in Chronic Hepatitis B Patients Efficiently Treated by Analogues. Mol Ther. 2014;22(3):675-84. PubMed PMID: 28141993. doi: 10.1038/mt.2013.274

69. Mandai M. PD-1/PD-L1 blockage in cancer treatment-from basic research to clinical application. Int J Clin Oncol. 2016;21(3):447. PubMed PMID: 26968586. doi: 10.1007/ s10147-016-0969-x

70. Bersanelli M, Buti S. From targeting the tumor to targeting the immune system: Transversal challenges in oncology with the inhibition of the PD-1/PD-L1 axis. World J Clin Oncol. 2017;8(1):37-53. PubMed PMID: 28246584. Pubmed Central PMCID: PMC5309713. doi: 10.5306/wjco.v8.i1.37

71. Gardiner D, Lalezari J, Lawitz E, DiMicco M, Ghalib R, Reddy KR, Chang KM, Sulkowski M, Marro SO, Anderson J, He B, Kansra V, McPhee F, Wind-Rotolo M, Grasela D, Selby M, Korman AJ, Lowy I. A randomized, double-blind, placebo-controlled assessment of BMS-936558, a fully human monoclonal antibody to programmed death-1 (PD-1), in patients with chronic hepatitis $C$ virus infection. PLoS One. 2013;8(5):e63818. PubMed PMID: 23717490. Pubmed Central PMCID: 3661719. doi: 10.1371/journal.pone.0063818 
72. Fuertes Marraco SA, Neubert NJ, Verdeil G, Speiser DE. Inhibitory Receptors Beyond T Cell Exhaustion. Front Immunol. 2015;6:310. PubMed PMID: 26167163. Pubmed Central PMCID: PMC4481276. doi: 10.3389/fimmu.2015.00310

73. Zarour HM. Reversing T-cell Dysfunction and Exhaustion in Cancer. Clin Cancer Res. 2016;22(8):1856-64. PubMed PMID: 27084739. Pubmed Central PMCID: PMC4872712. doi: 10.1158/1078-0432.CCR-15-1849

74. Anderson AC, Joller N, Kuchroo VK. Lag-3, Tim-3, and TIGIT: Co-inhibitory Receptors with Specialized Functions in Immune Regulation. Immunity. 2016;44(5):9891004. PubMed PMID: 27192565. Pubmed Central PMCID: PMC4942846. doi: 10.1016/j.immuni.2016.05.001

75. Pauken KE, Wherry EJ. Overcoming T cell exhaustion in infection and cancer. Trends in immunology. 2015;36(4):265-76. PubMed PMID: 25797516. Pubmed Central PMCID: 4393798. doi: 10.1016/j.it.2015.02.008

76. Pauken KE, Sammons MA, Odorizzi PM, Manne S, Godec J, Khan O, Drake AM, Chen Z, Sen DR, Kurachi M, Barnitz RA, Bartman C, Bengsch B, Huang AC, Schenkel JM, Vahedi G, Haining WN, Berger SL, Wherry EJ. Epigenetic stability of exhausted T cells limits durability of reinvigoration by PD-1 blockade. Science. 2016;354(6316):1160-5. PubMed PMID: 27789795. doi: 10.1126/science.aaf2807

77. Sen DR, Kaminski J, Barnitz RA, Kurachi M, Gerdemann U, Yates KB, Tsao HW, Godec J, LaFleur MW, Brown FD, Tonnerre P, Chung RT, Tully DC, Allen TM, Frahm N, Lauer GM, Wherry EJ, Yosef N, Haining WN. The epigenetic landscape of T cell exhaustion. Science. 2016;354(6316):1165-9. PubMed PMID: 27789799. doi: 10.1126/ science.aae 0491

78. Osburn WO, Fisher BE, Dowd KA, Urban G, Liu L, Ray SC, Thomas DL, Cox AL. Spontaneous control of primary hepatitis $\mathrm{C}$ virus infection and immunity against persistent reinfection. Gastroenterology. 2010;138(1):315-24. PubMed PMID: 19782080. Pubmed Central PMCID: 2889495. S0016-5085(09)01658-8 [pii]. doi: 10.1053/j. gastro.2009.09.017

79. Mehta SH, Cox A, Hoover DR, Wang XH, Mao Q, Ray S, Strathdee SA, Vlahov D, Thomas DL. Protection against persistence of hepatitis C. Lancet. 2002;359(9316):1478-83. PubMed PMID: 11988247.

80. Simmonds P. Genetic diversity and evolution of hepatitis C virus--15 years on. J Gen Virol. 2004;85(Pt 11):3173-88. PubMed PMID: 15483230.

81. Klenerman P, Fleming V, Barnes E. What are the prospects for controlling hepatitis C? PLoS Med. 2009;6(6):e1000096. PubMed PMID: 19529757. Pubmed Central PMCID: PMC2688087. doi: 10.1371/journal.pmed.1000096

82. Neumann AU, Lam NP, Dahari H, Gretch DR, Wiley TE, Layden TJ, Perelson AS. Hepatitis $C$ viral dynamics in vivo and the antiviral efficacy of interferon-alpha therapy. Science. 1998;282(5386):103-7.

83. Smith DB, Bukh J, Kuiken C, Muerhoff AS, Rice CM, Stapleton JT, Simmonds P. Expanded classification of hepatitis $C$ virus into 7 genotypes and 67 subtypes: updat- 
ed criteria and genotype assignment web resource. Hepatology. 2014;59(1):318-27. PubMed PMID: 24115039. Pubmed Central PMCID: PMC4063340. doi: 10.1002/ hep. 26744

84. Ray SC, Arthur RR, Carella A, Bukh J, Thomas DL. Genetic epidemiology of hepatitis C virus throughout Egypt. J Infect Dis. 2000;182(3):698-707. PubMed PMID: 10950762. doi: $10.1086 / 315786$

85. Cox AL, Mosbruger T, Mao Q, Liu Z, Wang XH, Yang HC, Sidney J, Sette A, Pardoll D, Thomas DL, Ray SC. Cellular immune selection with hepatitis $C$ virus persistence in humans. J Exp Med. 2005;201(11):1741-52. PubMed PMID: 15939790.

86. Ray SC, Fanning L, Wang XH, Netski DM, Kenny-Walsh E, Thomas DL. Divergent and convergent evolution after a common-source outbreak of hepatitis $\mathrm{C}$ virus. J Exp Med. 2005;201(11):1753-9. PubMed PMID: 15939791. Pubmed Central PMCID: PMC2213258. doi: 10.1084/jem.20050122

87. Theiler J, Yoon H, Yusim K, Picker LJ, Fruh K, Korber B. Epigraph: A Vaccine Design Tool Applied to an HIV Therapeutic Vaccine and a Pan-Filovirus Vaccine. Sci Rep. 2016;6:33987. PubMed PMID: 27703185. Pubmed Central PMCID: PMC5050445 (PCT/US15/54067) on "HIV Vaccines Comprising One or More Population Episensus Antigens." Authors LJP and KF have a significant financial interest in TomegaVax Inc., a company that may have a commercial interest in the results of this research and technology. This potential individual and institutional conflict of interest has been reviewed and managed by OHSU. doi: 10.1038/srep33987

88. Barouch DH, O’Brien KL, Simmons NL, King SL, Abbink P, Maxfield LF, Sun YH, La Porte A, Riggs AM, Lynch DM, Clark SL, Backus K, Perry JR, Seaman MS, Carville A, Mansfield KG, Szinger JJ, Fischer W, Muldoon M, Korber B. Mosaic HIV-1 vaccines expand the breadth and depth of cellular immune responses in rhesus monkeys. Nat Med. 2010;16(3):319-23. PubMed PMID: 20173752. Pubmed Central PMCID: PMC2834868. doi: 10.1038/nm.2089

89. Swadling L, Halliday J, Kelly C, Brown A, Capone S, Ansari MA, Bonsall D, Richardson R, Hartnell F, Collier J, Ammendola V, Del Sorbo M, Von Delft A, Traboni C, Hill AV, Colloca S, Nicosia A, Cortese R, Klenerman P, Folgori A, Barnes E. Highly-Immunogenic Virally-Vectored T-cell Vaccines Cannot Overcome Subversion of the T-cell Response by HCV during Chronic Infection. Vaccines (Basel). 2016;4(3). PubMed PMID: 27490575. Pubmed Central PMCID: PMC5041021. doi: 10.3390/vaccines4030027

90. Lavillette D, Morice Y, Germanidis G, Donot P, Soulier A, Pagkalos E, Sakellariou G, Intrator L, Bartosch B, Pawlotsky JM, Cosset FL. Human serum facilitates hepatitis C virus infection, and neutralizing responses inversely correlate with viral replication kinetics at the acute phase of hepatitis C virus infection. J Virol. 2005;79(10):6023-34. PubMed PMID: 15857988. Pubmed Central PMCID: PMC1091689. doi: 10.1128/ JVI.79.10.6023-6034.2005

91. Pestka JM, Zeisel MB, Blaser E, Schurmann P, Bartosch B, Cosset FL, Patel AH, Meisel H, Baumert J, Viazov S, Rispeter K, Blum HE, Roggendorf M, Baumert TF. Rapid 
induction of virus-neutralizing antibodies and viral clearance in a single-source outbreak of hepatitis C. Proc Natl Acad Sci U S A. 2007;104(14):6025-30. PubMed PMID: 17392433. Pubmed Central PMCID: 1851610. doi: 10.1073/pnas.0607026104

92. Folgori A, Capone S, Ruggeri L, Meola A, Sporeno E, Ercole BB, Pezzanera M, Tafi R, Arcuri M, Fattori E, Lahm A, Luzzago A, Vitelli A, Colloca S, Cortese R, Nicosia A. A T-cell HCV vaccine eliciting effective immunity against heterologous virus challenge in chimpanzees. Nat Med. 2006;12(2):190-7. PubMed PMID: 16462801. doi:10.1038/ nm1353

93. Prince AM, Brotman B, Lee DH, Pfahler W, Tricoche N, Andrus L, Shata MT. Protection against chronic hepatitis $\mathrm{C}$ virus infection after rechallenge with homologous, but not heterologous, genotypes in a chimpanzee model. J Infect Dis. 2005;192(10):17019. PubMed PMID: 16235167. doi: 10.1086/496889

94. Logvinoff C, Major ME, Oldach D, Heyward S, Talal A, Balfe P, Feinstone SM, Alter $\mathrm{H}$, Rice CM, McKeating JA. Neutralizing antibody response during acute and chronic hepatitis C virus infection. Proc Natl Acad Sci U S A. 2004;101(27):1014954. PubMed PMID: 15220475. Pubmed Central PMCID: PMC454180. doi: 10.1073/ pnas.0403519101

95. Timm J, Roggendorf M. Sequence diversity of hepatitis C virus: implications for immune control and therapy. World J Gastroenterol. 2007;13(36):4808-17. PubMed PMID: 17828811. Pubmed Central PMCID: PMC4611758.

96. Law M, Maruyama T, Lewis J, Giang E, Tarr AW, Stamataki Z, Gastaminza P, Chisari FV, Jones IM, Fox RI, Ball JK, McKeating JA, Kneteman NM, Burton DR. Broadly neutralizing antibodies protect against hepatitis $\mathrm{C}$ virus quasispecies challenge. Nat Med. 2008;14(1):25-7. PubMed PMID: 18064037. doi: 10.1038/nm1698

97. Grakoui A, Shoukry NH, Woollard DJ, Han JH, Hanson HL, Ghrayeb J, Murthy KK, Rice CM, Walker CM. HCV persistence and immune evasion in the absence of memory T cell help. Science. 2003;302(5645):659-62. PubMed PMID: 14576438. doi: $10.1126 /$ science. 1088774

98. Gruner NH, Gerlach TJ, Jung MC, Diepolder HM, Schirren CA, Schraut WW, Hoffmann R, Zachoval R, Santantonio T, Cucchiarini M, Cerny A, Pape GR. Association of Hepatitis C Virus-Specific CD8+ T Cells with Viral Clearance in Acute Hepatitis C. J Infect Dis. 2000;181(5):1528-36.

99. Cox AL, Mosbruger T, Lauer GM, Pardoll D, Thomas DL, Ray SC. Comprehensive analyses of CD8+ T cell responses during longitudinal study of acute human hepatitis C. Hepatology. 2005;42(1):104-12. PubMed PMID: 15962289.

100. Gerlach JT, Diepolder HM, Jung MC, Gruener NH, Schraut WW, Zachoval R, Hoffmann R, Schirren CA, Santantonio T, Pape GR. Recurrence of hepatitis C virus after loss of virus-specific CD4(+) T-cell response in acute hepatitis C. Gastroenterology. 1999;117(4):933-41. PubMed PMID: 10500077.

101. Thimme R, Oldach D, Chang KM, Steiger C, Ray SC, Chisari FV. Determinants of Viral Clearance and Persistence during Acute Hepatitis C Virus Infection. J Exp Med. 2001;194(10):1395-406. PubMed PMID: 11714747. 
102. Lechner F, Wong DK, Dunbar PR, Chapman R, Chung RT, Dohrenwend P, Robbins G, Phillips R, Klenerman P, Walker BD. Analysis of successful immune responses in persons infected with hepatitis C virus. J Exp Med. 2000;191(9):1499-512.

103. Schulze Zur Wiesch J, Ciuffreda D, Lewis-Ximenez L, Kasprowicz V, Nolan BE, Streeck H, Aneja J, Reyor LL, Allen TM, Lohse AW, McGovern B, Chung RT, Kwok WW, Kim AY, Lauer GM. Broadly directed virus-specific CD4+ T cell responses are primed during acute hepatitis $\mathrm{C}$ infection, but rapidly disappear from human blood with viral persistence. J Exp Med. 2012;209(1):61-75. PubMed PMID: 22213804. Pubmed Central PMCID: PMC3260872. doi: 10.1084/jem.20100388

104. Schulze zur Wiesch J, Lauer GM, Day CL, Kim AY, Ouchi K, Duncan JE, Wurcel AG, Timm J, Jones AM, Mothe B, Allen TM, McGovern B, Lewis-Ximenez L, Sidney J, Sette A, Chung RT, Walker BD. Broad repertoire of the CD4+ Th cell response in spontaneously controlled hepatitis $\mathrm{C}$ virus infection includes dominant and highly promiscuous epitopes. J Immunol. 2005;175(6):3603-13. PubMed PMID: 16148104.

105. Day CL, Lauer GM, Robbins GK, McGovern B, Wurcel AG, Gandhi RT, Chung RT, Walker BD. Broad specificity of virus-specific CD4+ T-helper-cell responses in resolved hepatitis C virus infection. J Virol. 2002;76(24):12584-95. PubMed PMID: 12438584.

106. McMahan RH, Golden-Mason L, Nishimura MI, McMahon BJ, Kemper M, Allen TM, Gretch DR, Rosen HR. Tim-3 expression on PD-1+ HCV-specific human CTLs is associated with viral persistence, and its blockade restores hepatocyte-directed in vitro cytotoxicity. J Clin Invest. 2010;120(12):4546-57. PubMed PMID: 21084749. Pubmed Central PMCID: PMC2994339. doi: 10.1172/JCI43127

107. Urbani S, Amadei B, Tola D, Massari M, Schivazappa S, Missale G, Ferrari C. PD-1 expression in acute hepatitis $\mathrm{C}$ virus (HCV) infection is associated with $\mathrm{HCV}$-specific CD8 exhaustion. J Virol. 2006;80(22):11398-403. PubMed PMID: 16956940.

108. Osburn WO, Snider AE, Wells BL, Latanich R, Bailey JR, Thomas DL, Cox AL, Ray SC. Clearance of hepatitis $C$ infection is associated with the early appearance of broad neutralizing antibody responses. Hepatology. 2014. PubMed PMID: 24425349. doi: 10.1002/hep. 27013

109. Forthal D, Hope TJ, Alter G. New paradigms for functional HIV-specific nonneutralizing antibodies. Current opinion in HIV and AIDS. 2013;8(5):393-401. PubMed PMID: 23924999. Pubmed Central PMCID: PMC4097845. doi: 10.1097/ COH.0b013e328363d 486

110. Bogdanos DP, Gao B, Gershwin ME. Liver immunology. Compr Physiol. 2013;3(2):567-98. PubMed PMID: 23720323. Pubmed Central PMCID: PMC4201126. doi: 10.1002/cphy.c120011

111. Kroy DC, Ciuffreda D, Cooperrider JH, Tomlinson M, Hauck GD, Aneja J, Berger C, Wolski D, Carrington M, Wherry EJ, Chung RT, Tanabe KK, Elias N, Freeman GJ, de Kruyff RH, Misdraji J, Kim AY, Lauer GM. Liver environment and HCV replication affect human T-cell phenotype and expression of inhibitory receptors. Gastroenterology. 2014;146(2):550-61. PubMed PMID: 24148617. Pubmed Central PMCID: PMC3946973. doi: 10.1053/j.gastro.2013.10.022 
112. Burke Schinkel SC, Carrasco-Medina L, Cooper CL, Crawley AM. Generalized Liver- and Blood-Derived CD8+ T-Cell Impairment in Response to Cytokines in Chronic Hepatitis C Virus Infection. PLoS One. 2016;11(6):e0157055. PubMed PMID: 27315061. Pubmed Central PMCID: PMC4912163. doi: 10.1371/journal. pone. 0157055

113. Trombetta JJ, Gennert D, Lu D, Satija R, Shalek AK, Regev A. Preparation of Single-Cell RNA-Seq Libraries for Next Generation Sequencing. Curr Protoc Mol Biol. 2014;107:4 22 1-4 17. PubMed PMID: 24984854 . doi: 10.1002/0471142727. $\mathrm{mb} 0422 \mathrm{~s} 107$

114. Shalek AK, Satija R, Adiconis X, Gertner RS, Gaublomme JT, Raychowdhury R, Schwartz S, Yosef N, Malboeuf C, Lu D, Trombetta JJ, Gennert D, Gnirke A, Goren A, Hacohen N, Levin JZ, Park H, Regev A. Single-cell transcriptomics reveals bimodality in expression and splicing in immune cells. Nature. 2013;498(7453):236-40. PubMed PMID: 23685454. Pubmed Central PMCID: 3683364. doi: 10.1038/nature12172

115. Buscarini L, Fornari F, Bolondi L, Colombo P, Livraghi T, Magnolfi F, Rapaccini GL, Salmi A. Ultrasound-guided fine-needle biopsy of focal liver lesions: techniques, diagnostic accuracy and complications. A retrospective study on 2091 biopsies. J Hepatol. 1990;11(3):344-8. PubMed PMID: 2290025.

116. Fabbri G, Mastrorosa I, Vergori A, Mazzotta V, Pinnetti C, Grisetti S, Zaccarelli M, Ammassari A, Antinori A. Reactivation of occult HBV infection in an HIV/HCV Co-infected patient successfully treated with sofosbuvir/ledipasvir: a case report and review of the literature. BMC Infect Dis. 2017;17(1):182. PubMed PMID: 28249574. Pubmed Central PMCID: PMC5333431. doi: 10.1186/s12879-017-2287-y

117. Belperio PS, Shahoumian TA, Mole LA, Backus LI. Evaluation of Hepatitis B Reactivation among 62,920 Veterans treated with Oral Hepatitis C Antivirals. Hepatology. 2017. PubMed PMID: 28240789. doi: 10.1002/hep.29135

\section{COPYRIGHT}

(C) Pathogens and Immunity 2017

This work is licensed under a Creative Commons Attribution 4.0 International License. To view a copy of this license, visit http://creativecommons.org/licenses/by/4.0/ 